\title{
English communication needs in Indonesian university
}

\author{
1Dwi Poedjiastutie*, 2Fida Akhyar, 1Masduki \\ ${ }^{1}$ English Language Education, Universitas Muhammadiyah Malang, Indonesia \\ 2Islamic Education Department, Sekolah Tinggi Agama Islam Al-Haudi Ketapang, West \\ Kalimantan, Indonesia \\ *Corresponding Author \\ Email: dpoedjiastutie@yahoo.com
}

\begin{abstract}
This paper explores the communication needs of students of English Department, Universitas Muhammadiyah Malang (ED UMM) as well as investigates the obstacles in fulfilling their needs. Collecting and analysing data on needs allows teachers to analyse the gap between what has been done and what needs to be done. Accordingly, a Needs Analysis can support the development and implementation of language policies at both macro and micro levels, with far-reaching consequences. The research participants were ED UMM students who are still attending speaking subjects and those who have already completed the speaking subjects. Two stages of data collections: Focus Group Discussion (FGD) and Questionnaire were employed. In FGD, the participants were selected purposively whereas convenience sampling was employed to get the participants for questionnaires. As many as 475 students or equal to $60 \%$ of ED students enrolled at English Department filled in the questionnaires. The findings indicate that to be able to speak in English was students first priority skill to master due to several reasons. To achieve the goals, improving teaching capacity and evaluating institutional policies are required.
\end{abstract}

Keywords: needs analysis; want-lack-necessities; communication needs; EFL learners; Indonesian context

$\begin{array}{llll}\text { Received: } & \text { Revised: } & \text { Accepted: } & \text { Published: } \\ \text { 17 January 2020 26 June 2020 } & \text { 25 July 2020 } & \text { 31 August 2020 }\end{array}$

\section{INTRODUCTION}

The needs for communication nowadays cannot be neglected. Many schools or institutions emphasize on developing communication for immediate used in any situation. Communication skill is the ability to use the language in various contexts or situations. Fitzpatrick \& O'Dowd (2014) announced that in the $21^{\text {st }}$ century, to be able to communicate properly is required to expand collaboration and to connect the world outside. Leong \& Ahmadi (2017) and Koran (2015) declare that the goals of learning English can be referred to the areas such as taking a part in academic study, obtaining job promotion, communicating socially, maintaining good relation, and understanding the 
Poedjiastuti, D., Akhyar, F. \& Masduki, M. (2020). English communication needs in Indonesian university. EduLite: Journal of English Education, Literature, and Culture, 5 (2), 287-303. DOI: http://dx.doi.org/10.30659/e.5.2.287-303

culture of the target language. Due to that, equipping the students with communication competence in the classroom should be directed to those mentioned above. In addition, communication competence will help students to increase their employability level for their future.

Clement \& Murugavel (2018) rated the communication skill (i.e. speaking) as the most important and preferred skill for the employment. Their study was conducted in Business and Finance of Chinese students and found that the interactional skill in business conversation on telephone and presentation skill are the preferred training course that students need to possess. They also claim that the support of appropriate course materials and flexible activities leads the students to the self-directed learning of speaking. Moreover, the continual collaboration between content experts and ELT teachers can produce better course plans and objectives.

Fang (2010) revealed the student's needs in communication skill in the university level. One hundred and fifty respondents participated in the study and it was found that the students rate speaking as the most important skill among others (listening, reading, writing). Majority students claimed that speaking can equip them to the preferable jobs such as entrepreneur, lawyer, and journalist and negotiation skill is viewed as the most needed.

Many scholars have broadcasted the issues of students' failure in acquiring communication skill in EFL countries. The common barrier in developing the student communication skill is an ineffective course which does not address the students' needs. This is because classroom teaching has spent too much time on lecturing which is contradictive with the idea of giving students a lot of opportunity to speak and share the ideas (Fang, 2010). This usually occurs in EFL contexts. The inability to provide appropriate courses and materials was due to the absence of NA (Andi \& Arafah, 2017).

A study by Alwasilah (2007) reported that one of the challenges of improving students' communication skill was the absence of an NA study for communication. For example, Idri's study (2014) found that students failed to improve their communication competence due to many factors, one of which was the lack of providing speaking topics relevant to the real-life situation. The study showed explicitly that, without an NA, study topics and materials for the English speaking were only based on teachers' intuitive decision which is frequently far from real life situation. Therefore, in attempt to overcome the inappropriate instruction for language learning, NA must be conducted to ensure that the learning has addressed the students' expectations.

\section{The roles of Needs Analysis (NA)}

Many scholars have declared that the function of NA is critical in designing the language program (Nunan, 1988; West, 1994; Brown, 1995). According to Nunan (1988), NA is a procedure or technique to gather any related information used for a syllabus design. Then, Brown (1995) added that NA is the systematic collection and analysis of both subjective and objective information required to determine and validate curriculum objectives that meet the language learning requirements of students in the context of particular institutions based on their learning and teaching situations. In 
short, NA is viewed as the first valuable data gathering useful for both identifying and connecting students' academic needs at present and for their future goals. Then, the data from NA is considered valuable to inform students to see the relevance between an English program they are currently undertaking and the requirement of English in the workplace.

The product of NA can be used to identify and determine students' learning goals. As Brown (1995) states, those goals and objectives can be deliberately used as the foundation for developing the courses, tests, materials, classroom activities, and evaluation in the language teaching (Poedjiastutie \& Oliver, 2017). Long \& Richard (2005) argue that language teachers and educators are suggested to be well-informed with the use of NA in order to avoid similar mistakes of the past. The fast growing of English teaching in globalization era and the development of stakeholders' needs, the roles and the concepts of NA has evolved significantly. Therefore, to understand the types of NA and which NA work best for our education context, the following section discuses some of the NA types.

\section{Target Situation Analysis (TSA)}

The concept of NA was firstly introduced by Munby (1978) in India, namely Target Situation Analysis (TSA). The purpose of this NA type is to determine the specific information about the language that students need to learn in its target situation. For example, the report from Alharby (2005) highlighted different groups of learners in medical fields; physician, dentist, pharmacist, and specialist had different needs in learning language. His study also identified two professions: pharmacist \& dentist that claimed English was frequently used in their jobs. In addition, since the target needs and the target level of performance are also conceptualized in TSA, this study also found that receptive skills (listening $\&$ reading) were highly demanded in pharmacists and dentists' workplaces. Therefore, it was suggested that learning activities and materials should rely on the authentic sources rather than having vocabulary repetition. The author of this study acknowledged that having a great level of understanding of medical circumstances, procedures, and instruction contributed to the health service professionalism.

The approach of TSA was basically directed to have higher relevance in communicative domain. It can be found in the employment demand where communication needs are the focus. The growing use of English in workplaces has brought the idea (TSA) to discover a need and made it into workable decision. Nurcahyo, Harahap, \& Gharnaditya (2015) assert that English is seen as the critical factor to prepare workers to be able to produce the maximum service on market needs, to be successful in the massive market competition, and to improve the use of technology. This can be found in the studies of Wettergren (2005), Alhamlan \& Baniabdelrahman (2015), and Ulum (2015) discussing how TSA was conducted as the approach of NA

\section{Present Situation Analysis (PSA)}

Present Situation Analysis (PSA) is the approach of NA whose objective is to find out the gap between learner's present situation and the target situation. In the PSA, Richterich and Chancerel (1980) included other sources of 
Poedjiastuti, D., Akhyar, F. \& Masduki, M. (2020). English communication needs in Indonesian university. EduLite: Journal of English Education, Literature, and Culture, 5 (2), 287-303. DOI: http://dx.doi.org/10.30659/e.5.2.287-303

information such as the students themselves, the teaching institutions, and the users (Li, 2014). For example, Alqunayeer \& Zamir's study (2016) investigated learning needs of Arabian EFL students at the university level. They found speaking and listening ability were the highest skills needed by the students compared to literacy and literary skills. The researcher tapped student's voices to collect the data. However, impromptu transition of a particular subject had led to the dissatisfaction progress to achieve the desired level of proficiency. Then, the revised curriculum was conducted in order to connect subjects. This revision was expected to lift up students' English competency level.

Using PSA Choi (2010) focused on discovering students' needs at a tourism department using the information of students' lack, want, and necessities in learning a language. The result showed that speaking skill and grammar were referred as their lack. This is stark contradiction with the necessity in the tourism industry such as hotels and travel agencies where speaking is the most needed skill according to the employers.

Another study focused on teacher's needs (Kusumoto, 2008; Bedoya, Valencia, and Montoya, 2015). For example, in Kusumoto's study (2008), PSA was conducted to improve and develop capacity of elementary English teachers in Japan. Nineteen recent topics for teaching were added into a design and material training since they claimed of having lack on pedagogical knowledge in teaching. He also added that the teachers should pose two competences in teaching; pedagogical knowledge and English proficiency. This is in lined with Aniroh (2009) who stated that beside considering on the language competencies, teachers also need to able to develop material that are relevant for students' preferences.

\section{Pedagogic Needs Analysis (PNA)}

Pedagogic Needs Analysis (PNA) focuses on contextual learning environment of the students. This refers to the contextual status of whether English is as the first language, the second, or a foreign language; Poedjiastutie \& Oliver (2017) add that English learning needed in a rural or urban setting or at the secondary or tertiary level can also be categorized as the contextual learning environment. Then, PNA becomes the data which provide the insight to determine students' learning and English needs by looking at the learning context.

Alhamlan and Baniabdelrahman (2015) conducted an NA study on EFL students at the secondary Arabian school context. It was found that five main aspects were revised for the improvement of curriculum such as professional needs, language skills and tasks, a preferred learning style, learning difficulties, and recommendations for EFL learning strategies. The research findings informed that students' needs of learning English fell into three categories such as: speaking fluency, speaking for social interaction, and speaking for job requirement. These expectations and needs emerged because the English learning in this context only focused on grammar and vocabulary Moreover, students' different levels of English competence were not taken into account in English teaching. Therefore, students' interest to participate in the 
course were also unlevel. The finding suggested that the curriculum and program designers need to make some improvements such as providing additional resources of English material, employing cooperative learning activities, and performing communicative tasks more. The authors acknowledged that this was done in order to increase students' motivation in learning English and to increase the number of students' study abroad. From the illustration above, it can be identified that different contexts of learning may result in different English learning needs reflected in the curriculum and syllabuses.

However, especially in Indonesian EFL contexts, the development of curriculum at the secondary level in Indonesia makes use of the top-down approach. A Top-down approach is the approach where the government through the Ministry of Education decides what students, regardless of their diversity of needs, must learn and acquire. The application of this approach comes along with several consequences. Poedjiastutie (2019) have argued that the freedom of schools to set up their English curriculum match with students' needs cannot be achieved. She further has stated that when the curriculum is designated by the authorities, there may be a discrepancy between what learners need to do with the targeted language in the future, and what the government wants them to achieve. This is contradicted to what has been recommended in the literature. Therefore, in addition to top-down decision, university are supposed to proactively create its own syllabuses and integrate with the one designated by authority to address a concern of a specific context such as at UMM. In this approach, stakeholders' voices more specifically ED UMM students are consulted to determine the learning objectives. Therefore, this study seeks the answers of these following research questions: (1) What communication needs that ED UMM students want to learn? and (2) What challenges are faced in fulfilling those needs?

\section{METHOD}

This study was qualitative in nature as it is typically centralized on exploring a certain phenomenon or capturing individuals' thoughts, feelings, interpretations, or process (Prior, 2008). Moreover, Fraenkel, Wallen, Hyun, (2006) argue that qualitative approach focuses on understanding a certain context of situations. Based on the opinions above, the students' communication needs were explored through multiple sources of data in order to interpret the holistic picture of the current issue. Thus, the data of this study were obtained through participants' goals, reasons, feelings, motives, perspectives and assumptions (Fraenkel, et.al, 2012).

The research participants were both students who were attending speaking subjects in the third semester and those who have finished the speaking subjects. There are two stages of data collection (Focus Group Discussion (FGD) and Questionnaire) in which each stage required different types of research participants selection. First. In FGD, the participants were selected purposively by inviting the captains of the classes or those who were capable to deliver their classmates' needs (wants) and lacks (concerns) especially in Speaking subjects. The FGD's interview was developed using semi-structured in order that the researcher can explore and go deeper to 
Poedjiastuti, D., Akhyar, F. \& Masduki, M. (2020). English communication needs in Indonesian university. EduLite: Journal of English Education, Literature, and Culture, 5 (2), 287-303. DOI: http://dx.doi.org/10.30659/e.5.2.287-303

ascertain their feelings, motives, perspectives to gain richer data. Each FGD consisted eight students (Fraenkel, et al, (2012, p.432) and Each FGD took approximately 90 minutes. The FGD were conducted twice and this is when the saturation point was achieved. During the discussion, their voices and opinions were recorded to avoid missing crucial information. Some of the semistructured interview questions are:

1. How important is communication skill compared to the other skills in job world?

2. What do you think about your goals of learning English Communication (speaking) in this university (related to your future job)?

3. What do you need in order to achieve your goals? Did English Department have equipped you with necessary communication competence in order to be able to reach your goal?

To validate and also to attain a more comprehensive and holistic picture about students' needs in communication, it was deemed necessary to distribute the questionnaires over the wider number of English Department students, The form of questionnaire followed the Likert Scale model in which students or participants' degrees of preferences were examined through the set of questions. As many as 475 students or equal to $60 \%$ of students who were enrolled at English Department filled in the questionnaires. In order to invite students' participation in this second stage, the researcher asked the help of speaking class teachers to distribute the questionnaire. However, students' participations remained voluntarily. The questionnaire questions were developed from the result of emergent themes revealed in FGDs.

Data collection and data analysis of this study were conducted through the iterative approach. It means that the whole process of interpreting the data involves researcher's role to frequently revisits the primary data in order to obtain the emerging themes, refining focus, and understandings (Srivastava $\&$ Hopwood, 2009). In the iterative approach, the data from each stage were fully completed before the data collection of the next began. In this study, the process of iterative approach was done in two stages; Focus Group Discussion (FGD) and questionnaire distribution.

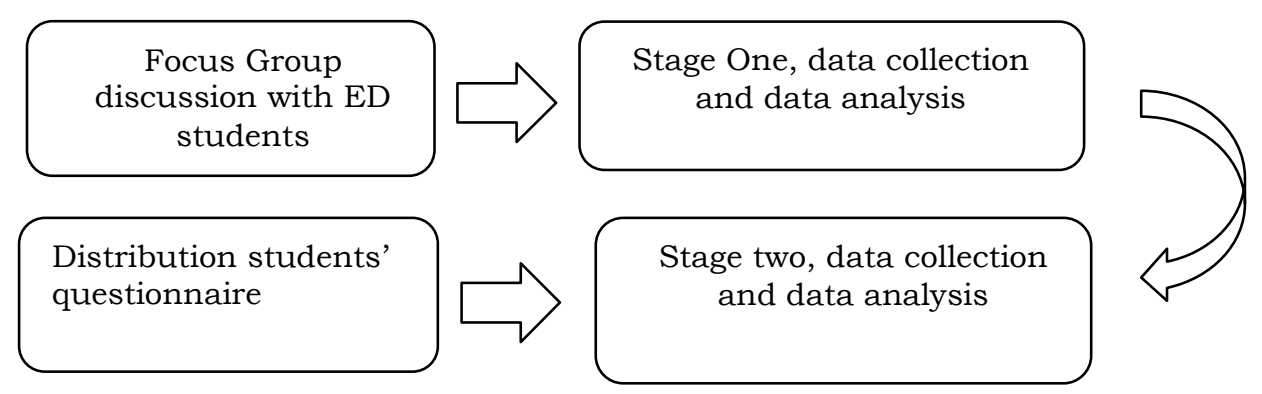

Figure 1. The stage of data collection in iterative approach

The data were analysed through several steps: First, the text data were read and re-read to attain an initial impression of the data. The next step was data 
redundancy process. This enables the researcher to sort the unnecessary information out (Fraenkel, et.al, 2012). Colour coding was conducted and followed by categorizing all the emerged themes using the overarching terms.

\section{Trustworthiness}

The trustworthiness of this study was examined using two ways; transferability and confirmability. Transferability can be achieved from using at least more than one instrument. It has been mentioned before that the researcher employed two stages of data collection procedures: Focus Group Discussion and questionnaire and the results were compared to find out either the convergence or divergence. Confirmability means all data from the research (constructs, assertions, and facts) can be traced back to their sources, and rationally be used to assemble the interpretations into structurally coherent and corroborating the wholes. As mentioned earlier that audio recording devices was used in FGD. This device provided data tracking for confirmation whenever the clarifications are needed.

\section{RESULT AND DISCUSSION \\ Student's communication needs}

From the FGD, almost all students said that to be able to speak in English was their first priority skill to master. This was due to several reasons, such as in general speaking will help them to secure a job in the employment. For instance, some students expected speaking to help them to gain a prestigious position in the workplace. They further said that this was due to the raising global competition where people from other countries would massively come to Indonesia to find a job. Thus, they were aware and willing to develop the communication competence in order to secure the job position.

In the questionnaire, students sought the urgency of mastering communication to lead to succeeding in an international collaboration program (48\%). Undeniably, to have a speaking ability like native speakers was also highly demanded by the students $(23 \%)$ as well as to succeed in academic achievement (15\%).

Table 1. The Goals of Communication

\begin{tabular}{|c|c|c|}
\hline Goals of Speaking & Frequency & Percentage \\
\hline $\begin{array}{l}\text { To succeed in any international collaboration } \\
\text { programs }\end{array}$ & 227 & $48 \%$ \\
\hline $\begin{array}{l}\text { To have a speaking ability like English native } \\
\text { speakers. }\end{array}$ & 111 & $23 \%$ \\
\hline To succeed in their academic achievement & 69 & $15 \%$ \\
\hline To gain prestigious position in the employment & 68 & $14 \%$ \\
\hline 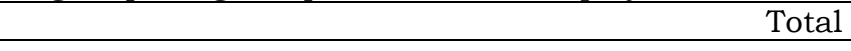 & 475 & $100 \%$ \\
\hline
\end{tabular}

In addition, students also expressed specific needs in the communication skill. Based on their response in FGD, they expected to master three skills; presentation, discussion, and these skills were considered important if they wanted to go for careers or to pursue higher educational levels. In teaching speaking, the teachers had to be able to integrate several teaching modes such as discussion, problem-solving, and presentation at a time. 
Poedjiastuti, D., Akhyar, F. \& Masduki, M. (2020). English communication needs in Indonesian university. EduLite: Journal of English Education, Literature, and Culture, 5 (2), 287-303. DOI: http://dx.doi.org/10.30659/e.5.2.287-303

The results of the FGDs were partly supported by the questionnaire. For example, in questionnaire, majority of students agreed that the presentation and discussion skill was crucial (36\%). Yet, others expected to master communication skills more than presentation one such as speaking for casual conversation $(33 \%)$, and speaking for the interview $(31 \%)$.

Table 2. The needs for specific communication skills

\begin{tabular}{|c|c|c|}
\hline Specific Communication Needs & Frequency & Percentage \\
\hline Speaking skill for presentation and discussion & 173 & $36 \%$ \\
\hline Speaking skill for casual conversation & 160 & $33 \%$ \\
\hline Speaking skill for interview & 142 & $31 \%$ \\
\hline & 475 & $100 \%$ \\
\hline
\end{tabular}

\section{The needs for teaching capacity improvement}

Needs can also be identified from the challenges experienced by students in learning a language. In this study, the researcher found several concerns which were described under the main categories; the concerns for improvement of teaching capacity.

In the fulfillment of students' communication needs, the researcher found several concerns in regards to the teachers' teaching capacity. In FGD, the concerns described the aspect of: (a) the inappropriate teaching feedback and assessment, (b) the undeveloped teaching materials, (c) and the unfocused syllabus.

\section{Inappropriate speaking assessment}

Based on the students' response in FGD, many of them expressed dissatisfaction of teacher's assessment or feedback since the focus was merely on the structural correction rather than other speaking indicators such as fluency, pronunciation, and vocabulary. Thus, discouraged students of making mistakes while speaking.

In my speaking class, ehmm sorry to say this, actually the rule in teaching and learning process is good, but sometimes when some of my friends talking or explaining something in English, the lecturer always corrects the grammar directly while they're still in the middle of speaking. The lecturer focuses more on the grammar mistakes. Maybe, it's good, but on the other side the students feel so depressed.

Students wanted speaking assessment should be able to build confidence and arouse the level of motivation. This assertion was supported by questionnaire where $42 \%$ of the participants wanted teachers to attend this.

\section{The undeveloped teaching materials}

Based on students' response in FGD, the given material was far from being interesting and unchallenging. Some of them said the topic material was similar to what they had already learnt in the senior high school. Besides, they also mentioned that teachers sometimes were not aware of the students' capacity level and tended to decide material below their proficiency range.

Students needed to be taught by a relevant material that did not only deal with the interesting topic, but also had to be challenging with the 
consideration on students' competency level. This assertion was supported by the questionnaire result, where $30 \%$ of them wanted the teachers to upgrade their material in accordance with students' capacity level.

The lecturers need to upgrade their materials when teaching speaking because sometimes, the material in Speaking 2 is easier than Speaking 1. They should know how to differentiate or create more challenging materials based on students' grade. From what I have experienced, there was no upgrade on the material. It's more like about the lecturer way or skill of teaching.

Participants in FGD said that the teachers had to upgrade the material, so the students would be easily move to the higher level of speaking competence.

From the assertions above, a challenging material is obviously needed by the students. This is supported by the questionnaire result where 28 of the participants demanded the teacher to attend significant development for each level of speaking material.

Table 3. The needs for appropriate speaking materials

\begin{tabular}{lcc}
\hline The Needs of Appropriate Teaching Materials & Frequency & Percentage \\
\hline $\begin{array}{l}\text { Selecting communication/speaking assessment to } \\
\text { increase student's confidence. }\end{array}$ & 201 & $42 \%$ \\
\hline $\begin{array}{l}\text { Selecting material matched with students' capacity } \\
\text { level. }\end{array}$ & 139 & $30 \%$ \\
\hline Developing material with clear direction in each level & 135 & $28 \%$ \\
\hline
\end{tabular}

The unfocused speaking materials and syllabuses

It obviously shows in the survey result that the students want the teaching material focusing on occupational purposes (EOP). However, EAP and EGP material were still highly needed with EAP 36\% and EGP 24\% respectively. EOP material related to the teaching job responded by $21 \%$ of the students, and EOP material related to the non-teaching job reached $19 \%$ of the student participants. Below was the table of need-based speaking materials from the students.

Table 4. The types of speaking materials

\begin{tabular}{|c|c|c|}
\hline Types of Speaking Materials & Frequency & Percentage \\
\hline I need English for Academic Purposes (EAP) & 169 & $36 \%$ \\
\hline I need English for General Purposes (EGP) & 113 & $24 \%$ \\
\hline I need EOP material for teaching related jobs & 100 & $21 \%$ \\
\hline I need EOP material for non-teaching jobs & 93 & $19 \%$ \\
\hline & 475 & $100 \%$ \\
\hline
\end{tabular}

Based on the data in Table 4, this required teacher's roles to facilitate the students specifically to get what might be best for their speaking syllabus.

Other teachers' capacity improvements were also mentioned in questionnaire, but were not mentioned in FGD such as directing learning based on the syllabus (32\%); measuring students' speaking levels appropriately $(28 \%)$, employing various teaching techniques $(25 \%)$, and improving students' vocabulary mastery $(15 \%)$. 
Poedjiastuti, D., Akhyar, F. \& Masduki, M. (2020). English communication needs in Indonesian university. EduLite: Journal of English Education, Literature, and Culture, 5 (2), 287-303. DOI: http://dx.doi.org/10.30659/e.5.2.287-303

Table 5. Other needs in teacher's capacity improvement

\begin{tabular}{|c|c|c|}
\hline The Needs of Other Teaching Improvement & Frequency & Percentage \\
\hline $\begin{array}{l}\text { Directing students' learning goals based on the } \\
\text { syllabus }\end{array}$ & 152 & $32 \%$ \\
\hline Measuring students' speaking level appropriately & 134 & $28 \%$ \\
\hline Employing variety of teaching techniques. & 123 & $25 \%$ \\
\hline $\begin{array}{l}\text { Enhancing students' vocabulary mastery for } \\
\text { each level }\end{array}$ & 66 & $15 \%$ \\
\hline $\begin{array}{ll}\text { Total } \\
\end{array}$ & 475 & $100 \%$ \\
\hline
\end{tabular}

\section{The needs for language program and policy improvement}

Not only with teaching capacity, students' concerns were also dealing with language program and policy. Language program improvement was defined as the efforts initiated by institution (ED UMM) to sustain the target learning, and to evaluate the existing policy. Further, in FGD, students sought the urgency from; (a) the quality of speaking teachers, (b) the establishment of exposure programs, (c) the speaking course duration, and (d) the concern for the proficient-based class.

The concern for teachers' quality

Most of students expressed a desire to have native teachers for their speaking class. In FGD, many of them had different viewpoints in describing what the native teacher is. Some of them said that native speaker could be anyone as long as they did not speak Bahasa Indonesia. Meanwhile, others described that native speaker was someone from English speaking countries or anyone as long as he/she was physically like European people even though English was not his/her first language. The reason of this, according to some students, was their lack of speaking Bahasa as the key for imitation how the English should like. Native teacher was highly demanded by students at ED UMM, and this assertion gained huge responses in the questionnaire from which $37 \%$ of the students showed the agreement for ED to have this support. Beside the great expectation of having native teachers to teach speaking class, some student criticized their attitude for not compliance with the student local culture. Students wanted the ED UMM chairman to make an agreement with them or to introduce the students' local culture, so they would be able to perform better teaching. For example,

In terms of the native teachers, I think the department should make an agreement with them. Because the case I found was when they taught students and students have the argumentation on a particular topic, they forced students to agree and say that you are wrong and I'm right. So, it is impacted to students' skill of communication. Students did not really want to talk. After that case, students felt really afraid to give their opinion. The English Department should make agreement or to set teaching rules so this will not happen again. And native speakers did not use whatever they want to use in their teaching. They should know at least our cultures too.

Some students also emphasized that local teachers can be appointed to teach communication class, but they had to have high communication competence so that they could become a good model for English students. In 
addition, the teachers' determination is of equal importance as their communication competence. This is because many students criticized the undetermined attitude coming from the local teachers. Based on the FGD, students said that some teachers come late for the class and had too many absences without prior notice. Due to this, the students felt that they got nothing from their class and would result in unsatisfactory development on the student speaking competence.

The needs for a number of exposure programs

Many students sought the urgency of the exposure program to raise their speaking competency level. They also claimed this would suit students of any level of proficiency. For example, low proficient students may possibly improve their skills in a small group learning. This sentiment was supported by $35 \%$ respondents agree to have more English exposures.

Besides, students wanted ED UMM teachers and ED chairman to become a role model for everyone to speak English inside or outside the classrooms. Some students highlighted rules to sustain the benefit of the existing exposure programs. They admit that in English Day, many students were still using and talking in Bahasa. Students suspected that ED chairman has not yet designed the systematic ways to overcome the problem and therefore, failed to increase the number of participants in the existing program.

\section{Streaming class based on proficiency}

Some students in FGD wanted a speaking class with the same level of proficiency. In FGD, one participant argued that one class consisting of mixlevel of ability students made the teachers decides to decrease the level of the materials, and this accordingly some students would easily get bored with unchallenging topics. Therefore, some of the participants wanted streaming class-based on the proficiency. This assertion was supported by $23 \%$ of the students in the questionnaire.

Table 6. Program and policy improvement

\begin{tabular}{|c|c|c|}
\hline $\begin{array}{l}\text { The Needs for Language Program and Policy } \\
\text { Improvement }\end{array}$ & Frequency & Percentage \\
\hline $\begin{array}{l}\text { The preference of having native teachers in speaking } \\
\text { subject }\end{array}$ & 176 & $37 \%$ \\
\hline $\begin{array}{l}\text { The needs for having a number of English exposure } \\
\text { programs }\end{array}$ & 165 & $35 \%$ \\
\hline The needs for streaming class based on proficiency & 111 & $23 \%$ \\
\hline $\begin{array}{l}\text { The needs for having longer duration for speaking } \\
\text { subject }\end{array}$ & 23 & $5 \%$ \\
\hline $\begin{array}{ll} & \text { Total } \\
\end{array}$ & 475 & $100 \%$ \\
\hline
\end{tabular}


Poedjiastuti, D., Akhyar, F. \& Masduki, M. (2020). English communication needs in Indonesian university. EduLite: Journal of English Education, Literature, and Culture, 5 (2), 287-303. DOI: http://dx.doi.org/10.30659/e.5.2.287-303

\section{DISCUSSION}

These findings basically fall into two categories: the urgency of communication which lead to students' wants and expectations and the barriers which lead to the lack and necessities.

\section{Communication urgency}

The fact that English is now used for communication in this globe is no longer arguable. Communication competence which reflected through the interaction between teacher and students in classroom become a central in teaching and learning process (Rustandi and Mubarok, 2017).

In many societies English is the language of business executives, academic life and of politics. This language is often linked to important jobs and positions (Passaung, 2003) As a consequence, many people perceive that someone with a high level of English competences is also successful. Further, many people within Indonesia, including those involved in governing the nation, also believe that for Indonesia to become a successful and developed country, the education system should equip learners with English competency. English communication deems important as it provides access, such as to obtain jobs overseas or within Indonesia, and to gain employment with joint venture companies. Similar phenomena are also revealed in this finding.

\section{Communication barriers}

However, one of the barriers to fulfil students' needs and expectations to be able to communicate English profoundly is teachers' capacity and commitment. Teacher's capacities are usually linked with the ability to use English and the ability to understand teaching pedagogy. Shen (2013) claims that fluency means a quality where the teachers are able to speak a language easily and well, to communicate ideas effectively, and to produce speech continuously without difficulties. A study conducted by Agustin, Warsono, and Mujiyanto (2015) revealed that many teachers inevitably delivered the English (L2) subjects using Bahasa Indonesia (L1). Teacher's commitment refers to an internal force that drives teachers to show enhanced job performance (Tsui $\&$ Cheng, 1999). Teacher commitment has been recognized as one of the most critical factors in effective teaching. Thereby, teachers with high level of commitment can make a difference to the learning and achievement of their students.

As it is mentioned in the findings, teachers were still emphasising on grammar rather than focusing on learners for communicative environment. This may bring serious impacts especially the capacity and the opportunity of the learners to communicate is neglected. Besides, in most speaking classrooms, the learners were presented with uninspiring content and language exercises which lacked of any clear communication focus. Accordingly, there is a need for improved teaching capacities to develop relevant classroom instruction pertaining to the students' communication development. Besides, there is a need for continuous NA approaches to be undertaken so that the ever-changing gaps between what has been taught and 
what are the current pedagogical practices in regards to English teaching and learning can be accurately identified.

A number of researches showed the similarities with this present study. Many claimed that ESP curricula which are based on NA would eventually prepare students for their future professional (Clement and Murugrave, 2018, Choi, 2010; Alharby, 2005; Fitzpatrick \& Dowd, 2014; Kasumoto, 2008;). However, preparing students for workplaces should not be the only focus. If NA data are used wisely and appropriately, it enables to disclose other needs such as psychological. For instance, From the FGD, a student said "...when my friends talking or explaining something in English, the lecturer always corrects the grammar directly while they're still in the middle of speaking. The lecturer focuses more on the grammar mistakes. Maybe, it's good, but on the other side the students feel so depressed especially when many students present”. This finding is similar to Subekti (2020) that teachers are expected to give learners more opportunities to speak in front of fewer number of audiences. Shall they ask learners to speak in public, learners should be given enough time to prepare for their performance. The teachers' assessment on students' communication ability may impact on students' psychological aspects. In other words, teachers and educators should be aware of the emergent psychological needs which are greatly overlooked when assessing needs.

Those psychological concerns emerge since this study utilizes specific approach which provides a room for students to express their feelings and concerns as much as they want with fewer students. Utilizing FGD, this present study is capable to produce richer data on teachers' attitude and ED management behaviors and its impact on the students. It is recommended that this study needs to be urgently followed up to examine the psychological needs of students.

As we may know, NA studies were large-scale ones utilizing closed-ended questionnaire. In other words, many researches usually focused on what students' want and expect of how their English should look like upon completion of the undergraduate studies (ability and skill aspect). Understanding students' response in closed-ended questionnaire alone may lead to false decision since questionnaire is less capable to generate richer data which are necessary to find out the emergent problems (lack). Using a large-scale approach is considered inadequate to inform the university decision makers to establish or to revise the policies. However, questionnaire was still used in this study because of its time-saving characteristic.

\section{CONCLUSION}

In this study, students' communication needs were revealed under the three main categories; students' learning needs, the needs for teaching capacity improvement, and the needs for language program development. For the learning needs, the students expected to be able to communicate for international collaboration, job opportunities, academic achievement.

However, to fulfill the students' learning goals and needs, several challenges emerge. For example, the students expected the teachers to provide appropriate speaking feedback and assessment, to select appropriate speaking material and syllabus, to measure their speaking level based on their 
Poedjiastuti, D., Akhyar, F. \& Masduki, M. (2020). English communication needs in Indonesian university. EduLite: Journal of English Education, Literature, and Culture, 5 (2), 287-303. DOI: http://dx.doi.org/10.30659/e.5.2.287-303

performance, to utilize various teaching techniques, and to develop their vocabulary. In regards with English Department policy, students wanted native speaking teachers and more committed teachers in teaching. They also expected the teachers to establish more English exposure programs, to extend course duration, to stream class based on students' proficiency, to create smaller class-size for speaking. It is advised that ED UMM should not restrict its students only to the courses offered in the ED curriculum and syllabuses. Providing different sorts of teacher training using experienced people from a wide range of backgrounds such as English teachers, curriculum designers, English material developers, translators and interpreters, travel agents, early childhood teachers, foreign language course teachers, motivators, psychologists, school counsellors, home schooling teachers, university professors and classroom researchers would give students and ED UMM teachers with information about the current needs, issues, and trends of English learning. This approach will possibly connect classrooms with real life employment and reduce the current mismatch.

\section{REFERENCES}

Agustin, D. T., Warsono, Mujianto, J. (2015). The Use of Bahasa Indonesia (L1) in the Intensive English (L2) Classroom. English Education Journal (EEJ), $5(1), 1-9$.

Al-Hamlan, S., \& Baniabdelrahman, A. A. (2015). A needs analysis approach to EFL syllabus development for second grade students in secondary education in Saudi Arabia: A descriptive analytical approach to students' needs. American International Journal of Comtemporary Research, 5(1), 118-145.

Alharby, M. (2005). ESP target situation needs analysis: The English language communicative needs as perceived by health professionals in the Riyadh area. Unpublished PhD dissertation, Athens: The University of Georgia.

Ali, H. \& Salih, A. (2013). Perceived views of language teachers on the use of needs analysis in ESP materials writing. English Language Teaching, 6(3), 11-19.

Alqunayeer, H. S., \& Zamir, S. (2016). Needs analysis of Saudi EFL female students: A case study of Qassim University. Journal of Curriculum and Teaching, 5(1), 87-104. https://doi.org/10.5430/jct.v5n1p87

Alwasilah, C. (2007). Redesigning Indonesian course in the undergraduate curriculum: The Indonesian case. Paper presented at ASAIHIL Conference, Lingnan University, Hong Kong, April 12, 2007.

Andi, K., \& Arafah, B. (2017). Using needs analysis to develop English teaching materials in initial speaking skills for Indonesian college students of English. The Turksih Online Journal of Design, Art and Communication, Special Edition (April), 419-436. https://doi.org/10.7456/1070ASE/045 
Aniroh, K. (2015). From English as a general school subject onto English as a medium for learning specific subjects: The need to shift in the teaching orientation. TEFLIN Journal, 2O(2), 169-179. https://doi.org/10.15639/TEFLINJOURNAL.V20I2/169-179

Bedoya, P. A., Valencia, L. M., \& Montoya, J. C. (2015). Students' needs analysis in an EFL program for university professors. HOW Journal, 22(2), 11-36. http://dx.doi.org/10.19183/how.22.2.118

Brown, J. D. (1995). The elements of language curriculum: A systematic approach to program development. In R. Howard \& G. Brown (Eds.). Teacher education for LSP (pp. 80-89). Clevedon, England: Multilingual Matters.

Choi, K. (2010). Needs analysis of students of tourism English. Proceeding of the 10th Conference of PAAL, (pp. 57-68). Retrieved from http://paaljapan.org/resources/proceedings/PAAL10/pdfs/kyunghee.pd $\underline{f}$

Clement, A. \& Murugavel, T. (2018). English for the workplace: The importance of English language skills for effective performance. The English Classroom, 20(1), 1-16.

Fang, F. (2010). A discussion on developing students' communicative competence in college English teaching in China. Journal of Language Teaching and Research, 1(2), 111-116. https://doi.org/10.4304/jltr.1.2.111-116

Fitzpatrick, A., \& O'Dowd, R. (2014). English at work an analysis of case reports about English language training for the $21^{\text {st }}$ century workforce. The International Research Foundation for English Language Education, Cengage Learning. Available at https://www.tirfonline.org/wpcontent/uploads/2012/03/TIRF_EnglishAtWork_ExecutiveSummary_20 12.pdf

Fraenkel, J. R., Wallen, N.E., \& Hyun, H.H. (2012). How to design and evaluate research in education (8th ed.). New York: Mc Graw-Hill.

Gao, J. (2007). Designing an ESP course for Chinese university students of business. Asian ESP Journal. 3(1). Retrieved from http://www.asianespjournal.com/April_2007_gj.php

Ghenghesh, P. (2013) Students and teachers of engineering speak out! What do you really need? $A W E J, 4(1), 11-27$.

Idri, N. (2014). Algerian university students' pragmatic failure when speaking EFL: Teachers' views and strategies. The European Procedia Social and Behavioural Sciences, 1, 229-236.

Koran, S. (2015). The role of teachers in developing learners' skill. Conference paper on the 6th International Visible Conference on Educational Studies and Applied Linguistics, At Erbil, Iraq. https://www.researchgate.net/publication/322112785_The_Role_of_Tea chers_in_Developing_Learners'_Speaking_Skill 
Poedjiastuti, D., Akhyar, F. \& Masduki, M. (2020). English communication needs in Indonesian university. EduLite: Journal of English Education, Literature, and Culture, 5 (2), 287-303. DOI: http://dx.doi.org/10.30659/e.5.2.287-303

Kusumoto, Y. (2008). Needs analysis: Developing a teacher training program for elementary school homeroom teachers in Japan. Second Language Studies, 26(2), 1-44.

Leong, L. \& Ahmadi, S. M. (2017). An analysis of factors influencing learners' English-speaking skill. International Journal of Research in English Education, 2(1) 34-41. http://ijreeonline.com/article-1-38-en.html

Li, J. (2014). Needs analysis: An effective way in business English curriculum design. Theory and Practice in Language Studies, 4(9), 1869-1874. https://doi.org/10.4304/tpls.4.9.1869-1874

Long, M. H. \& Richard (2005). Second language needs analysis. Cambridge: Cambridge University Press.

Munby, J. (1978). Communicative syllabus design. Cambridge: Cambridge University Press.

Nunan, D. (1988). Syllabus design. Oxford: Oxford University Press.

Nurcahyo, R., Harahap, R. H., \& Gharnaditya, D. (2015). Prepare SME in facing AEC 2015 through English training program to obtain the export market. Journal The WINNERS, 16(2), 96-107.

Passaung, N. (2003). Teaching English in an 'acquisition-poor environment': An ethnographic example of a remote Indonesian EFL Classroom. Unpublished thesis. Department of Linguistics University of Sydney. Retrieved from http://www.languageonthemove.com/wpcontent/uploads/2013/01/Pasassung_English-language-learning-inIndonesia.pdf

Poedjiastutie, D. (2019). A complex process of autonomy curriculum approach in Indonesia. The Journal of Asia TEFL, 16(3), 1051-1058.

Poedjiastutie, D., \& Oliver, R. (2017). Exploring students' learning needs: Expectation and challenges. English Language Teaching, 10(10). 124-133. https://doi.org/10.5539/elt.v10n10p124

Prior, L. (2008). Document analysis. The Sage Encyclopedia of Qualitative Research Methods (pp. 230-231). https://doi.org/10.4135/9781412963909

Richterich R. and Chancerel J.L. (1980). Identifying the needs of adults learning a foreign language. New York: Pergamon Press.

Rustandi, A., \& Mubarok, A. H. (2017). Analysis of IRF (Initiation-ResponseFeedback) on classroom interaction in EFL speaking class. Edulite: Journal of English Education, Literature and Culture, 2(1), 239-250. http://dx.doi.org/10.30659/e.2.1.239-250

Srivastava, P., \& Hopwood, N. (2009). A practical iterative framework for qualitative data analysis. International Journal of Qualitative Methods, 8(1), 76-84. https://doi.org/10.1177/160940690900800107

Subekti, A.S. (2020). Self-perceived communication competence and communication apprehension: A study of Indonesian college students. 
Edulite: Journal of English Education, Literature and Culture, 5(1), 14-31. http://dx.doi.org/10.30659/e.5.1.14-31

Tsui, K. T., \& Cheng, Y. C. (1999). School organizational health and teacher commitment: A contingency study with multi-level analysis. Educational Research and Evaluation, 5, 249-268.

Ulum, Ö. G. (2015). A needs analysis study for preparatory class ELT students. European Journal of English Language Teaching, 1(1), 14-29. West, R. (1994). Needs analysis in language teaching. Language Teaching, 27 (1), 1-19.

Wettergren, S. T. (2005). Second language needs analysis in the workplace: A case study of Hispanic immigrant manufacturing workers. (Retrospective Theses and Dissertation). Iowa State University Digital Repository.

Yu, X., \& Xiao, Y. (2013). A course design guideline for legal English teaching in Chinese tertiary education: From the perspective of content-based instruction. Theory and Practice in Language Studies, 3(7), 1123-1128. 